\title{
Autogenic Relaxation with Aromaterapy Cendana on The Quality Of Sleeping in Patients Diabetes Type 2 Mellitus
}

\author{
Lono Wijayanti, Erika Martining Wardani, Difran Nobel Bistara \\ Universitas Nahdlatul Ulama Surabaya, East Java, Indonesia \\ Corresponding author:lono@unusa.ac.id
}

\begin{abstract}
Background: Type 2 DM can not be cured, but can be controlled by controlling blood glucose levels and improving sleep quality of sufferers. Decreased sleep quality can cause endocrine and metabolic disorders such as abnormal glucose tolerance, insulin resistance, and reduced response to insulin (Caple and Grose, 2011).

Purpose: This study aimed to analyze the effect of autogenic relaxation with sandalwood aromatherapy on the quality of sleep in patients with type 2 diabetes mellitus in the Sidoarjo Public Health Center.

Method: This research is a Quasy Experiment research pre-post control group design. The population in this study were all type $2 \mathrm{DM}$ beneficiaries and the sample used was 60 respondents using simple random sampling. The independent variable is autogenic relaxation with sandalwood aromatherapy while the dependent variable is sleep quality. The data in this study are numerical so that it is analyzed using parametric statistical tests namely paired sample $t$ test and independent sample $t$ test.

Results: The results showed that the quality of pre and post sleep based on the Paired t-test obtained $\mathrm{p}$ value $=0,000(\mathrm{p}<0.05)$, and in the intervention group an increase in sleep quality was greater than the control group marked by the t-value of 22,40 . Based on the independent sample t-test, $p=0,000$ was obtained, so it can be concluded that there were significant differences in sleep quality changes between the control and intervention groups.
\end{abstract}

Conclusion: Autogenic relaxation with sandalwood aromatherapy has a positive impact on sleep quality. The use of autogenic relaxation with sandalwood aromatherapy can be considered as one of the interventions in improving sleep quality that can be carried out routinely even on a daily basis especially for people with type 2 diabetes.

Keywords: Sleep Quality, Autogenic Relaxation With Sandalwood Aromatherapy, Type 2 Diabetes Mellitus 


\section{BACKGROUND}

Type $2 \mathrm{DM}$ can not be cured, but can be controlled by controlling blood glucose levels. Sleep disturbance is one of the risks of diseases such as DM and vice versa type 2 DM can also cause sleep disorders (Black \& Hawks, 2014; Taub \& Redeker, 2008). Sleep disturbance is related to the risk of developing DM, where individuals who sleep less than 4 hours a night have a risk of experiencing impaired glucose tolerance compared with those who get enough sleep (Spiegel et al, 2009).

Sleep disorders are common in people with Diabetes Mellitus, based on research results in Sao Paolo showing that $32 \%$ of patients with diabetes mellitus suffer from sleep disorders (Teixeira et al, 2009). Based on the current facts at the Taman Sidoarjo Health Center, it shows that 6 out of 8 DM sufferers say they often wake up during sleep, because they often urinate at night. Decreased sleep quality can cause endocrine and metabolic disorders such as abnormal glucose tolerance, insulin resistance, and reduced response to insulin (Caple and Grose, 2011). Sleep disturbances especially Non Rapid Eye Movements (NREM) for 3 days can result in a decrease in insulin sensitivity of around 25\% (Spiegel et al., 2009).

The prevalence of type 2 diabetes is associated with lifestyle changes, high calorie food consumption habits, lack of activity, smoking, obesity and sleep disorders (Holt et al, 2010). Based on World Health Organization data, the prevalence of diabetics around the world was around 415 million in 2015 (WHO, 2016). Indonesia ranks 7th out of all countries in the world, based on International Diabetes Federation data, the number of people with type 2 diabetes mellitus in Indonesia was 9.1 million in 2014, rising to 10 million in 2015 (IDF, 2015). According to Riskesda data, a number of diabetics in East Java in 2007 amounted to 275,462, increasing to 605,974 patients in 2013 (Ministry of Health, Republic of Indonesia, 2014).

Based on these facts prevention efforts are needed to help sufferers of DM overcome their complaints so as to minimize their impact on health. Autogenic relaxation is an effort to minimize complaints of DM sufferers and has its own uniqueness. The main source of autogenic relaxation is coming from oneself using words or short sentences that can make the mind calm. Some research results show that there are many benefits of autogenic relaxation for clients with constipation, ulcers, hemorrhoid, tuberculosis, DM and low back pain. Autogenic relaxation is a research that is recommended to be further developed as a therapy for lowering blood sugar levels because the mechanism of action is similar to the principle of meditation which is the principle of concentration (DiNardo, 2009).

Autogenic Relaxation can be combined with aroma therapy. Clary sage aromatherapy has an effect on the inhaler to improve the physical and psychological condition so that it becomes better (Ravinda et al, 2014). Each essential oil has unique pharmacological effects such as vasodilators, antibacterial, antiviral, sedative and adrenal stimulating. According to Jaelani (2009) the gift of sandalwood aromatherapy helps reduce depression, overcome insomnia, stress, feelings of sadness and is very beneficial for meditation. Based on the above it is very interesting to do autogenic relaxation research with sandalwood aromatherapy in people with DM.

\section{OBJECTIVE}

This study aimed to analyze the effect of autogenic relaxation with sandalwood aromatherapy on the quality of sleep in patients with type 2 diabetes mellitus in the Sidoarjo Public Health Center

\section{METHOD}


This research is a type of quantitative research using quasy experimental design, with the method of pre post test control group design. The research was carried out at the Taman Sidoarjo Puskesmas location. The total population of the study was 170 type 2 diabetes mellitus sufferers, 60 respondents were divided into two groups, 30 control groups and 30 intervention groups with simple random sampling. The intervention group was given autogenic relaxation treatment with sandalwood aromatherapy while in the control group only deep breath relaxation. The research instrument uses the Pittsburgh Sleep Quality Index (PSQI) in the form of a questionnaire to measure sleep quality. Data were analyzed using paired sample $t$ test and independent sample $t$ test.

The participants were assured that their engagement was voluntary, and that anonymity, privacy, and confidentiality of the data were guaranteed. Furthermore, they were informed about the purpose and the method of the study before signing a written informed consent. The questionnaires were distributed to eligible participants at the Taman Sidoarjo Public Health Center, and respondents were asked to complete and return them in the same time

\section{RESULTS}

General data

1. Gender

Table.1 Distribution of Frequency of Respondents by Gender.

\begin{tabular}{lllll}
\hline \multirow{2}{*}{ Variable } & \multicolumn{2}{l}{ Interventions } & \multicolumn{2}{l}{ Control } \\
\cline { 2 - 6 } & $\mathbf{n}$ & $\mathbf{\%}$ & $\mathbf{n}$ & $\mathbf{\%}$ \\
\hline 1) Male & 10 & 33 & 9 & 30 \\
\hline 2) female & 20 & 67 & 21 & 70 \\
\hline Total & $\mathbf{3 0}$ & $\mathbf{1 0 0}$ & $\mathbf{3 0}$ & $\mathbf{1 0 0}$ \\
\hline
\end{tabular}

Source: Primary data 2019

Based on table 1 shows that most respondents were female in both groups.

2. Age

Table.2 Distribution of Frequency of Respondents by Age.

\begin{tabular}{lclll}
\hline \multirow{2}{*}{ Variabel } & \multicolumn{2}{l}{ Interventions } & \multicolumn{2}{l}{ Control } \\
\cline { 2 - 5 } & $\mathbf{n}$ & $\mathbf{\%}$ & $\mathbf{n}$ & $\mathbf{\%}$ \\
\hline 1) $26-35$ & 0 & 0 & 1 & 3 \\
\hline 2) $36-45$ & 3 & 10 & 0 & 0 \\
\hline 3) $46-55$ & 4 & 13 & 9 & 30 \\
\hline 4) $56-65$ & 12 & 40 & 15 & 50 \\
\hline 5) $66-$ over & 11 & 37 & 5 & 17 \\
\hline Total & $\mathbf{3 0}$ & $\mathbf{1 0 0}$ & $\mathbf{3 0}$ & $\mathbf{1 0 0}$
\end{tabular}

Source: Primary data 2019

Based on table 2 shows that the largest percentage of respondents aged 56-65 years in both groups.

\section{Special Data}


1. Sleep Quality

Table 3. Changes in the quality of pre and post given autogenic relaxation with sandalwood aromatherapy

\begin{tabular}{lcccc}
\hline \multirow{2}{*}{ Respondent } & \multicolumn{2}{c}{ Sleep Quality } & t & \multirow{2}{*}{$\boldsymbol{\rho}^{*}$} \\
\cline { 2 - 3 } & $\begin{array}{c}\text { Before } \\
\text { (Mean } \pm \text { SD) }\end{array}$ & $\begin{array}{c}\text { After } \\
\text { (Mean } \pm \text { SD) }\end{array}$ & & \\
\hline Control Group & $10,7 \pm 1,32$ & $10,07 \pm 1,01$ & 5,83 & 0,00 \\
Intervention Group & $11 \pm 2,06$ & $4,27 \pm 0,87$ & 22,40 & 0,00 \\
\hline
\end{tabular}

* $\mathrm{p}<0,05$ Based on paired t-test

Source: Primary Data 2019

Based on the statistical test results Paired t-Test obtained $p$ value $=0.00$. $P$ value $<0.05$ so that it can be concluded that there is a significant change in sleep quality before and after an intervention is given. The intervention group increased sleep quality greater than the control group marked by the $t$ value of 22.40 .

Table 4. Difference in sleep quality difference between pre and post respondents given autogenic relaxation with sandalwood aromatherapy

\begin{tabular}{lclrl}
\hline $\begin{array}{l}\text { Sleep } \\
\text { quality }\end{array}$ & $\begin{array}{l}\text { Control Group } \\
(\text { Mean } \pm \text { SD) }\end{array}$ & \multicolumn{2}{l}{$\begin{array}{l}\text { Intervention Group Mean } \\
(\text { Mean } \pm \text { SD) }\end{array}$} & $\begin{array}{l}\text { Difference } \\
\boldsymbol{\rho}^{*}\end{array}$ \\
\hline Difference value & $0,60 \pm 0,56$ & $6,76 \pm 1,65$ & 6,16 & 0,00 \\
\hline
\end{tabular}

${ }^{*} \mathrm{p}<0,05$ Based on independent $t$-test

Table 4 shows that the difference in the average change in the quality of sleep pre and post given autogenic relaxation using sandalwood aromatherapy in the control group and the intervention group was 6.16 points. Based on the results of the statistical tests of the independent sample $t$-Test, the value of $p=0.00$ was obtained. $P$ value $<0.05$ so that it can be concluded that there are significant differences in sleep quality changes between the control group and the intervention group.

\section{DISCUSSION}

The results of measurement of sleep quality variables in patients with type $2 \mathrm{DM}$ in the intervention group showed that all respondents experienced improved sleep quality after being given autogenic relaxation using sandalwood aromatherapy. The paired t-test results showed that both the control group and the intervention group experienced changes with a value of $p$ $=0.00$. Average sleep quality improvement, however, in the control group there was only an increase of 5.83. Meanwhile, the intervention group $t$ value greater than 22.40. The intervention group got an autogenic relaxation intervention using sandalwood aromatherapy for one week, which means autogenic relaxation using sandalwood aromatherapy had an effect on improving sleep quality in patients with type $2 \mathrm{DM}$.

The average PSQI score of respondents in this study before the intervention was given 10.67 in the control group and 11.03 in the treatment group. Assessment of sleep quality with PSQI includes subjective assessment of sleep quality, sleep efficiency, length of sleep, perceived impact related to sleep problems. The results of the summation of the score from PSQI will illustrate the quality of sleep, namely poor sleep quality indicated by the highest value.

Sleeping with a small span of time can cause the decline in the hormone serotonin, resulting in a person easily stressed and depressed. In addition, emotions are easily ignited if 
the body starts to feel tired. An increase in stress hormone levels, the brain can not think better, and more easily depressed if sleep needs are reduced. Conversely, the body getting enough sleep can be healthier, relaxed and not easily stressed. Stress and lack of sleep cause high cortisol levels. With the very high cortisol hormone, it triggers an increase in blood sugar levels. Getting enough sleep can reduce excess cortisol by up to 50\% (Tortora in Qoys \& Iqbal, 2014).

Sleep quality problems are often experienced by people who are elderly. As in this study, based on table 2 shows that the majority of respondents aged 56-65 years. According to Luce and Segal in Nugroho's book (2012) it is mentioned that age is an important part that affects sleep quality. The occurrence of complaints of sleep quality with age. This is supported by the statement of Martono \& Pranarka (2011), that in old age there will be excretion of cortisol and GH (Growth Hormone) followed by fluctuating changes in body temperature. Melatonin, a hormone that is usually excreted at night. Levels of this hormone will decrease with age, so that in old age there is a decrease in sleep quality.

The same opinion was expressed by Akmal (2012) that older people spend more time in bed to start sleeping, the frequency of awakening to be high, tend to experience fatigue, drowsiness, decreased sleep efficiency and easy to fall asleep during the day. It is important for elderly people to pay attention to the quality of sleep (Winanto, 2009). Quality sleep does not only depend on the amount, but depends on meeting the body's needs for sleep. A good range of sleep depends on each individual and one of the important indicators of a person's sleep quality needs is the condition of waking up. A person who is healthy and fresh when he wakes up shows enough sleep needs.

Based on the results of the study showed that the majority of respondents were female. The results of this study are consistent with Kurnia's research (2017) which says that the majority of respondents who suffer from type 2 diabetes are female with a total of 40 respondents $(58.8 \%)$ compared to males totaling 28 (41.2\%). These sex characteristics cannot be said to be a cause of sleep quality disruption but only provide information that in this study most of the women were female.

This autogenic relaxation exercise with the aroma of sandalwood therapy begins with slowly taking a deep breath while inhaling sandalwood aromatherapy and feeling a relaxed sensation in the body when releasing breath. Repeat again, inhale more slowly and deeper than before, causing a relaxing effect involving the parasympathetic nerve and the central nervous system. The function of one of the parasympathetic nerves is to reduce the production of the hormone adrenaline or epineprin (stress hormone) and increase the secretion of the nonadrenaline or nonepineprin hormone which makes the decrease in tension and anxiety so that it becomes more relaxed and calm (Manocha, 2014).

Aromatherapy has a positive impact on humans. The effect of aromatherapy on our body is that its fragrant aroma can stimulate sensory nerves, receptors and ultimately affect other organs so that it can have a powerful effect on emotions. The aroma is also very useful for meditation (MacKinnon, 2014). In addition, the fragrance of sandalwood aromatherapy can reduce depression, fragrant sandalwood is believed to overcome the problem of insomnia and other problems related to stress.

The implementation of autogenic relaxation with sandalwood aromatherapy is able to make respondents become more relaxed and calm. A sense of calm will generate positive emotions that will be transmitted to the limbic system and cerebral cortex with a complex level of connectivity between the brain stem-hypothalamus-prefrontal left and right hippocampus-amygdala. This transmission causes a balance between the synthesis and secretion of neurotransmitters such as GABA (Gama Amino Butiric Acid) and GABA 
antagonists by the hippocampus and amygdala. Dopamine, serotinin, and noreepineprin produced by prefrontal. Acetylcholine, endorphins (natural opiates in the body's calming effect) by the hypothalamus. ACTH (Adrenocortico Releasing Hormone) is also balanced, thus affecting the balance of the adrenal cortex in secreting cortisol, normal cortisol levels are able to act as stimulators for both specific and nonspecific immunological immune response (Fatimah, 2012; Manocha, 2014). A calm state of the soul can create a balance in the body that can reduce all psychological disorders including disorders of sleep quality.

The sleep quality of the respondents became better after being given autogenic relaxation with the aroma of sandalwood therapy as evidenced by the respondents' say that it is quick to start sleeping, it is not easy to wake up, if you wake up it is easy to start sleeping again. The body feels refreshed after waking up from sleep, in terms of strength which usually sleeps 4-5 hours per day so it increases to 7-8 hours per day.

This research is supported by research conducted by Agus (2016), which is about the effect of autogenic relaxation techniques on the fulfillment of sleep needs in postoperative patients in the lotus room of Dr. Soehadi Prijonegoro Sragen Hospital, which states that there is an influence of autogenic relaxation techniques on fulfilling sleep needs with values $p$ value 0,000 . Also a study conducted by Istiana and colleagues (2018) about the effect of autogenic relaxation on insomnia in hypertensive patients at RSD Bagas Waras Klaten which states that the average insomnia score before being given autogenic relaxation was 9.86 and after being given autogenic relaxation 6, 00 Wilcoxon signed ranks test results showed $p$ value $=0.00$. This means that there is an influence between autogenic relaxation on insomnia in hypertensive patients.

The same opinion was said by Triyanto (2014) that relaxation techniques are increasingly being performed proven effective in reducing tension, anxiety, overcoming insomnia and asthma, and relaxation will give results after 3 times of exercise. Individuals who have practiced autogenic relaxation every day on a regular basis, ie once a day with a span of 15-20 minutes found better health conditions and a more balanced emotional condition, better coping abilities, improved sleep quality and reduced anxiety (Saunders, 2007).

\section{ACKNOWLEDGEMENTS}

Thanks to the Ministry of Research, Technology, and Higher Education Republic of Indonesia for the support for this research (Ristekdikti).

\section{REFERENCE}

Akmal, S.A. 2012. Diagnosis dan Penatalaksanaan Insomnia Pada Lanjut Usia. http://infopenyakitdalam.com diakses 15 Juni 2019

Arifin Z. 2011. Analisis hubungan kualitas tidur dengan kadar glukosa darah pasien diabetes mellitus tipe 2 di rumah sakit umum Propinsi Nusa Tenggara Barat. Jakarta: Universitas Indonesia.

Agus Supriyanto. 2016. Pengaruh Teknik Relaksasi Autogenik terhadap Pemenuhan Kebutuhan Tidur Pada Pasien Post Operasi Di Ruang Teratai RSUD Dr Soehadi Prijonegoro Sragen.

http://www.digilib.stikeskusumahusada.ac.id/files/disk1/29/01-gdl-agussupriy-1431-1-artikelh.pdf diakses tanggal 23 maret 2019. 
Andina Setyawati. 2010. Pengaruh Relaksasi Otogenik Terhadap Kadar Gula Darah Dan Tekanan Darah Pada Klien Diabetes Mellitus Tipe 2 Dengan Hipertensi Di Instalasi Rawat Inap RS Di D.I.Y Dan Jawa Tengah. Jakarta: Universitas Indonesia.

American Diabetes Association. 2017. Standards of medical care in diabetes 2017. Clinical and Applied Research and Education. 40(1): 1-2.

Bowden, A, Lorenc, A., dan Robinson, N. 2012. Autogenic training as a behavioural approach to insomnia: A prospective cohort study. Primary Health Care Research \& Development 13:175-185

Cauter VE, Holmback U, Knutson K, Leproult R, Nedeltcheva A, Pannain S et al. 2007. Impact of sleep and sleep loss on neuroendocrine and metabolic function. Hormone Research. 67(1): 2-9.

Cuellar GN, Ratcliffe JS. 2008. A comparison of glycemic control, sleep, fatique and depression in type 2 diabetes with and without restless legs syndrome. J clin sleep med. 4(Suppl 1): 50-6.

Caple \& Grose. 2011. Sleep and Hospitalization Evidenced-Based Care Sheet. Sleep and Hospitalization. Cinahl Information Ststem.

DiNardo, M.M. 2009. Mind Bodies Therapy In Diabetes Management Diabetes Spectrum, 22 (1) http://spectrum.diabetesjournals.org/content/22/1/30.full-text.pdf diakses tanggal 10 Agustus 2018

Fatimah FS. 2012. Efektifitas Mendengarkan Al Quran terhadap Derajat Insomnia Pada Lansia di Selter Dongkelasari Sleman Yogyakarta.

Gustamigo, ZP. 2015 Kualitas Tidur Penderita Diabetes Mellitus. Fakultas Kedokteran Universitas Lampung.

Irawan D. 2010. Prevalensi dan Faktor Risiko Kejadian Diabetes Melitus Tipe 2 di Daerah Urban Indonesia (Analisa Data Skunder Riskesdas 2007). Jakarta: Universitas Indonesia.

Istianna N, Agustina N W \& Halimah H. 2018. Pengaruh Relaksasi Autogenik Terhadap Insomnia Pada Penderita Hipertensi di RSD Bagas Waras Klaten. Jurnal Keperawatan Respati Yogyakarta, 5(3), September 2018, 444-450

Jessy Kurnia, Mulyadi \& Julia V.Rottie. 2017. Hubungan Kualitas Tidur Dengan Kadar Glukosa Darah Puasa pada Penderita Diabetes Mellitus Tipe 2 di RS Pancaran Kasih Gmim Manado. e-Journal Keperawatan (e-Kp) Vol.5 No.1.

Khasanah, Khusnul, Wahyu. Kualias Tidur Lansia. Jurnal Nursing Studies. Volume 1, 2012. http://ejournal-s1.undip.ac.id/index.php/jnursing. Diakses pada 20 januari 2019

Kementerian Kesehatan Republik Indonesia. 2012. Tahun 2030 Prevalensi Diabetes Melitus di Indonesia Mencapai 21,3 Juta Orang. http://www.depkes.go.id/index.php/berita/press- 
release/414-tahun-2030-prevalensi-diabetes-melitus-di-indonesia-mencapai-213-jutaorang.html diakses tanggal 15 April 2019.

MacKinnon, K. 2014. Aromatherapy: Art or Science? Highlight of Aromaterapy in Medicine Today. Inet Continuing Education brought to pharmacists by Pfizer Inc., USPG Vol 8 No 8

Manocha, R., 2014. Silence Your Mind: Improve Your Happiness in Just 10 Minutes a Day with This New Approach to Meditation, Sydney: Hachette.

Maifrisco, O. 2008 Pengaruh Aromaterapi Terhadap Tingkat stress Mahasiswa. Avaiable from URL: www.indoskripsi.com diakses pada tanggal 10 Januari 2019.

Martono, H. H \& Pranarka, K. 2011. Buku Ajar Boedhi-Darmojo Geriatri (Ilmu Kesehatan Usia Lanjut) Edisi 4 cetakan ke-3. Jakarta: Balai Penerbit Fakultas Kedokteran Universitas Indonesia.

Nugroho, W. 2012. Keperawatan Gerontik \& Geriatrik Edisi 3. Jakarta: EGC

Qoys Muhammad, Iqbal Al-Halaj. 2014. Pengaruh Dzikir Menjelang Tidur Terhadap Kualitas Tidur Lanjut Usia di Panti Tresna Werdha Budi Mulia di Jakarta Timur. Skripsi. Jakarta Kedokteran dan Ilmu Kesehatan.

Ravindra N., Kamble., Metha P.P., Shinde VM., (2014). Aromatherapy as complementary and alternative medicine systematic review.World journal of pharmaceutical research.144-160.

Roepke SK \& Ancoli-Israel S. 2010. Sleep Disorders in The Elderly. Indian Journal Medical Research 131 February 2010: 302-310

Saunders S. 2007. Autogenic Therapy: Short Term Therapy for Long Term Gain. British Autogenic Society, Chairman http://www. Autogenic-therapy.org.uk.

Spiegel K, Tasall E, Leproult R, Cauter EV. 2009. Sleep loss : a novel risk factor for insulin resistance and Type 2 diabetes. J Appl Physiol. 99(54): 2008-19.

Taub ML, Redeker SN. 2008. Sleep disorder, glucose regulation and type 2 diabetes. Biology Research Nursing. 9(3): 231-43.

Triyanto E. 2014. Pelayanan Keperawatan Bagi Penderita Hipertensi Secara Terpadu. Yogyakarta: Graha Ilmu.

Varvogli, L dan Darviri, C. 2011. Stress management techniques: evidence-based procedures that reduce stress and promote health: Health Science Journal, 10(2) 75-80

Winanto. 2009. Tidur dalam Sudut Pandang Ilmiah. http://www.winanto.typepad.com diakses 17 Februari 2019. 